\title{
NITROGEN FERTILIZATION AND NARROW PLANT SPACING STIMULATES SUNFLOWER PRODUCTIVITY
}

\author{
Muhammad AWAIS*, Aftab WAJID, Ashfaq AHMAD, Muhammad Farrukh SALEEM, Muhammad Usman \\ BASHIR, Umer SAEED, Jamshad HUSSAIN, M.Habib-ur-RAHMAN \\ University of Agriculture, Department of Agronomy, Agro-climatology Lab., Faisalabad, PAKISTAN \\ *Corresponding author: mauaf26@gmail.com
}

Received: 28.03.2014

\begin{abstract}
Plant population exerts a strong influence on growth and seed yield because of its competitive effect both on the vegetative and reproductive development. For evaluating the effect of different plant populations $(83,333$, 66,666 and 55,555 plants $\left.\mathrm{ha}^{-1}\right)$ and $\mathrm{N}$ rates $\left(90,120\right.$ and $\left.150 \mathrm{~kg} \mathrm{~N} \mathrm{ha}^{-1}\right)$ on sunflower hybrid (Hysun-33) a field experiment was conducted during spring seasons of 2012 and 2013 using split plot design with three replications at Agronomic Research Area, University of Agriculture, Faisalabad. Results revealed that each $\mathbf{N}$ increment enhances the total dry matter, achene yield and its components while oil contents were undesirably affected. During both years, total dry matter, achene yield and harvest index were detected from 83, 333 plants $\mathrm{ha}^{-1}$. Contradictorily, yield components (head diameter, number of achenes per head and 1000-achene weight) were highest in 55,555 plants $\mathrm{ha}^{-1}$ treatment. Application of $150 \mathrm{~kg} \mathrm{~N} \mathrm{ha}^{-1}$ in 83,333 plants ha plant $^{-1}$ population was best treatment to attain maximum achene yield.
\end{abstract}

Keywords: correlation, nitrogen, plant population, regression, achene, sunflower, yield.

\section{INTRODUCTION}

Pakistan has been facing a persistent shortage of vegetable oils for many years (Muniret al., 2007) due to increasing population (Iqbalet al., 2007) and many other critical factors. The native edible oil production does not equal to increasing demand of population. Thus country is forced to import edible oil in massive quantities involving giant expenditure in foreign exchange. Pakistan will have to seem away from the traditional oilseed crops (cottonseed, rapeseed and mustard and groundnut) to appreciably increase local production of vegetable oil (Khaliq and Cheema, 2005). Rapeseed and mustard oil cannot be used (more than 5\%) for ghee formation (P.O.D.B., 2006) as it contains higher concentration of erucic acid. Similarly, cotton oil contents and its fiber are negatively correlated, as is generally grown for its fiber (Govt. of Pakistan, 2009b). The most important nonconventional oil seed crops are sunflower, soybean and safflower (Khaliq and Cheema, 2005). Among different non-conventional oilseed crops sunflower has appeared as an important crop (Badar et al., 2002; Khaliq and Cheema, 2005; Ahmad et al., 2009) that can reduce edible oil import (Khan et al., 2003; Hu et al., 2008). Sunflower can be grown nearly all over Pakistan (Khaliq and Cheema, 2005). In Pakistan area under sunflower crop was 0.28 million hectares with oilseed production of 0.378 million tons and oil production 0.14 million tons(Govt. of Pakistan, 2013).
Reduction in sunflower production was due to many factors like improper plant density, nitrogen fertilizer level and irrigation application etc. Availability of different nutrients is the main factor that controls the sunflower yield (Habib etal., 2006). Fertilizer application boosts the fertility status of soil; enhance the nutrients uptake by the plant that finally increase crop yield (Adediranet al., 2004). However in intensive agriculture, nitrogen is the major nutrient determining sunflower yield (Habib et al., 2006; Abdel-Motagally and Osman, 2010). Nitrogen, the most deficient element in our soils, being an integral part of structural and functional protein, chlorophyll and nucleic acid plays a vital role in crop development. Increased supply of nitrogen results in faster rate of plant growth, productivity and photosynthetic capacity of leaves ( Fayyaz-Ul-Hassan et al., 2005). Leaf area, leaf production, light interception and photosynthesis rate were reduced by the nitrogen deficiency (Tothet al., 2002; Nasimet al., 2011). Increased rates of nitrogen reduced the oil contents of sunflower (Ali etal., 2004; Osman and Awed, 2010; Bakhtet al., 2010a; Nasimet al., 2011; Hussainet al., 2011) but the reduction was relatively small, and it was over compensated by increase in seed yield (Scheineret al., 2002). Higherachene weight and number of achene per head were obtained from the application of 150 or $225 \mathrm{~kg} \mathrm{~N}^{-1}$ (Ali et al., 2011).Plant population has a crucial significance for achieving highest yield potential of a sunflower crop. Plant population affects the radiation interception, evapotranspiration and 
finally water use efficiency of growing crop (Saleemet al., 2008; Yasinet al., 2011). Killi, (2004) reported that head diameter, total number of seeds per head, seed yield per head and 1000-seed weight were highest with highest plant population (71420 plants $\mathrm{ha}^{-1}$ ).

The aim of the present study was to determine effect of different plant population and $\mathrm{N}$ rates on growth and yield of sunflower under agro environmental conditions of Faisalabad, Pakistan.

\section{MATERIALS AND METHODS}

Field experiment was conducted to study the response of sunflower to different plant populations and $\mathrm{N}$ rates. Investigation was carried out for two consecutive years i.e. during 2012 and 2013 at the Agronomic Research Area, University of Agriculture, Faisalabad, Pakistan. The climate of Faisalabad $\left(31^{\circ} 26^{\prime} \mathrm{N}, 7^{\circ} 06^{\prime} \mathrm{E}\right)$ region is subtropical and arid to semi-arid at an altitude of 184 meters. The experimental field was quite uniform and its soil was sandy clay loam. The soil was analyzed for its physio-chemical properties; each year before sowing the crop (Table 1).

Table 1. Physiochemical properties of soil $(0-30 \mathrm{~cm})$

\begin{tabular}{lcc}
\hline Soil characteristics & $\mathbf{2 0 1 2}$ & $\mathbf{2 0 1 3}$ \\
\hline Physical & & \\
Sand (\%) & 59 & 63 \\
Silt (\%) & 17 & 15 \\
Clay (\%) & 24 & 22 \\
Chemical & & \\
pH & 7.8 & 7.62 \\
Organic matter (\%) & 1.07 & 1.09 \\
Total soluble salt (\%) & 12.31 & 12.27 \\
Nitrogen (\%) & 0.05 & 0.06 \\
Available P (ppm) & 6.7 & 6.8 \\
Available K (ppm) & 189 & 195 \\
\hline
\end{tabular}

Weather summary of experimental site was presented in Fig. 1. The experiment was laid out in a randomized complete block design with split plot arrangement keeping plant population $(83333,66666$ and 55555) in main plots and $\mathrm{N}$ rates $\left(90,120\right.$ and $\left.150 \mathrm{~kg} \mathrm{ha}^{-1}\right)$ in sub plots. The experiment was replicated thrice; measuring a net plot size of $3.6 \mathrm{~m} \times 5 \mathrm{~m}$. Sunflower hybrid (Hysun-33) was sown on $1^{\text {st }}$ March during both the years. In each season the experimental field was wetted by heavy irrigation (locally called rouni) and seedbed was prepared by one deep ploughing and two cultivations, each followed by planking. Planting was done on $60 \mathrm{~cm}$ apart ridges in both experiments. Plant to plant distance was kept according to plant population treatments $(20 \mathrm{~cm}$ for $83,333,25 \mathrm{~cm}$ for 66,666 and $30 \mathrm{~cm}$ for 55,555plants $\mathrm{ha}^{-1}$ ). Phosphorus and potassium was used @ $60 \mathrm{~kg} \mathrm{ha}^{-1}$ each in all plots. Nitrogen, phosphorus and potassium were applied in the form of Urea, DAP and SOP. One third dose of nitrogen and full of the $\mathrm{P}$ and $\mathrm{K}$ was applied at sowing. Remaining $\mathrm{N}$ was used in two splits; $1 / 3$ at first irrigation and $1 / 3$ at the flowering stage. All other cultural practices such as hoeing, earthing up and plant protection measures were kept normal for the crop. Table 2 describes the crop husbandry operations during both years. Growth sampling was conducted at a ten days interval. In each plot, four plants were harvested at the ground level. The plants that were cut were separated into leaves and stems. A subsample $(50 \mathrm{~g})$ of each fraction was taken and dried in forced draft oven at $70^{\circ} \mathrm{C}$ for at least $48 \mathrm{~h}$ up to constant weight to calculate total dry weight $\left(\mathrm{g} \mathrm{m}^{-2}\right)$ at each harvest. The crop growth rate (CGR) was calculated as suggested by Hunt (1978) at each sampling date.

$$
\mathrm{CGR}=(\mathrm{W} 2-\mathrm{W} 1) /(\mathrm{T} 2-\mathrm{T} 1)
$$

Where, $\mathrm{W}_{1}$ and $\mathrm{W}_{2}$ were the total dry weights harvested at times $T_{1}$ and $T_{2}$, respectively. Mean CGR was calculated by averaging all CGR values calculated at each destructive harvest. At final harvest, two rows with a length of $5 \mathrm{~m}$ for each plot were harvested. A subsample of 10 plants was obtained to measure the yield components. All the heads including subsample were threshed mechanically to estimate achene yield of entire plot and converted into $\mathrm{kg} \mathrm{ha}^{-1}$. For the measurement of achene moisture, the subsample of $500 \mathrm{~g}$ was weighed, dried and then weighed again, so the final yield was corrected to $10 \%$ moisture. The sunflower head diameter was measured from the 10 randomly taken plants and average head diameter was determined. Five heads per plot were threshed, their grains counted and average grains per head was computed. Five samples each of thousand achenes were taken from each plot, weighed with an electric balance and averaged. The total dry matter was determined and for this purpose whole plot was harvested, weighed and converted into $\mathrm{kg} \mathrm{ha}^{-1}$. Harvest index (HI) was measured as the ratio of achene yield to biological yield, and expressed in percentage.

$$
\mathrm{HI}=(\text { Achene yield } / \text { Biological yield }) \times 100
$$

Data collected were analyzed statistically by employing the Fisher's analysis of variance technique and significance of treatments means was tested using least significance difference (LSD) test at $5 \%$ probability level (steel et el., 1997). 


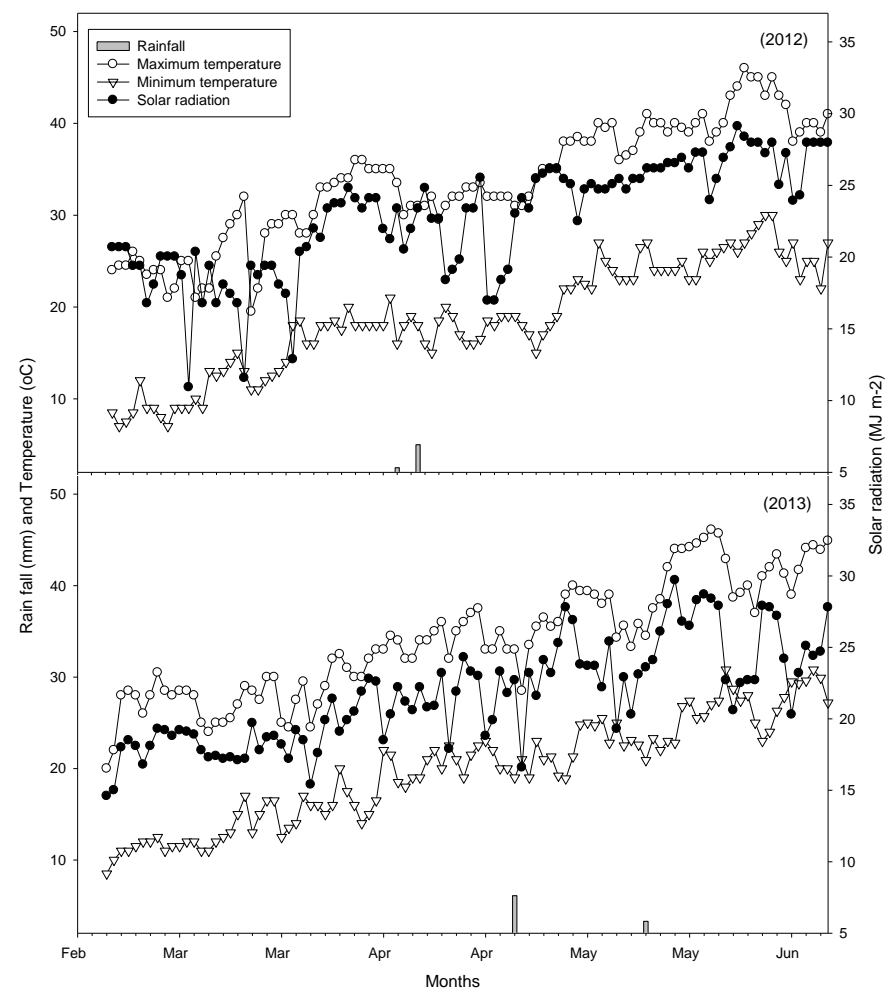

Figure 1. Mean climatic conditions of agro-ecological conditions of Faisalabad.

Table 2. Crop husbandry operations in experiment during 2012 and 2013

\begin{tabular}{|c|c|c|}
\hline Operations & 2012 & 2013 \\
\hline Sowing dates & 01.03 .2012 & 01.03 .2013 \\
\hline Crop establishment & 11.03.2012 & 11.03.2013 \\
\hline \multicolumn{3}{|l|}{ Fertilizer application } \\
\hline P(DAP) @60 kg ha-1 & 01.03 .2012 & 01.03 .2013 \\
\hline $\mathrm{K}(\mathrm{SOP}) @ 60 \mathrm{~kg} \mathrm{ha}^{-1}$ & 01.03 .2012 & 01.03 .2013 \\
\hline $\mathrm{N}$ (Urea) & \multicolumn{2}{|c|}{$\mathrm{N}$ application in three splits according to treatments } \\
\hline 1st Dose & 01.03 .2012 & 01.03 .2013 \\
\hline 2nd Dose & 20.03.2012 & 20.03.2013 \\
\hline 3rd Dose & 21.04.2012 & 18.04.2013 \\
\hline Thinning & 19.03.2012 & 19.03.2013 \\
\hline Earthing Up & 18.04.2012 & 15.04 .2013 \\
\hline \multicolumn{3}{|l|}{ Irrigations } \\
\hline 1 & 20.03 .2012 & 20.03 .2013 \\
\hline 2 & 07.04 .2012 & 05.04 .2013 \\
\hline 3 & 21.04.2012 & 18.04 .2013 \\
\hline 4 & 11.05 .2012 & 06.05 .2013 \\
\hline 5 & 25.05 .2012 & 21.05 .2013 \\
\hline \multicolumn{3}{|l|}{ Sampling dates } \\
\hline 1 & 20.03 .2012 & 20.03 .2013 \\
\hline 2 & 30.03 .2012 & 30.03 .2013 \\
\hline 3 & 09.04 .2012 & 09.04 .2013 \\
\hline 4 & 19.04 .2012 & 19.04 .2013 \\
\hline 5 & 29.04 .2012 & 29.04 .2013 \\
\hline 6 & 09.05 .2012 & 09.05 .2013 \\
\hline 7 & 19.05 .2012 & 19.05 .2013 \\
\hline Harvesting & 12.06.2012 & 08.06 .2013 \\
\hline
\end{tabular}




\section{RESULTS AND DISCUSSION}

Plant population significantly affected the crop growth rate (CGR) during both experimental years (Table 3 ). The sunflower achieved more CGR (15.11 and $15.32 \mathrm{~g} \mathrm{~m}^{-2} \mathrm{~d}^{-1}$ in 2012 and 2013, respectively) when plant population was maintained at 83,333 plants $\mathrm{ha}^{-1}$. Lowest mean CGR (13.54 and $13.77 \mathrm{~g} \mathrm{~m}^{-2} \mathrm{~d}^{-1}$ during 2012 and 2013, respectively) was noted from 55,555 plants ha $^{-1}$ treatment. The treatment $\mathrm{P}_{2}\left(66,666\right.$ plants $\left.\mathrm{ha}^{-1}\right)$ was statistically similar to $\mathrm{P}_{1}\left(83,333\right.$ plant $\left.\mathrm{ha}^{-1}\right)$ in both study years. The effect of $\mathrm{N}$ rates on CGR was also significant (Table 3 ). More CGR (14.85 $\mathrm{g} \mathrm{m}^{-2} \mathrm{~d}^{-1}$ ) was observed in plots where $\mathrm{N}$ was applied @ $150 \mathrm{~kg} \mathrm{ha}^{-1}$ in 2012 and it was statistically at par with plots fertilizes with $120 \mathrm{~kg} \mathrm{~N} \mathrm{ha}^{-1}$.
Same trend was noted in next study year and $\mathrm{N}_{2}$ treatment remained at par with $\mathrm{N}_{3}$ treatment. The minimum CGR of $13.93 \mathrm{~g} \mathrm{~m}^{-2} \mathrm{~d}^{-1}$ was recorded in $\mathrm{N}_{1}\left(90 \mathrm{~kg} \mathrm{ha}^{-1}\right)$ during both experimental years. However, this treatment was also at par with $\mathrm{N}_{2}\left(120 \mathrm{~kg} \mathrm{~N} \mathrm{ha}^{-1}\right)$. Increased vegetative growth due to $\mathrm{N}$ application finally leads to enhancement in CGR.Nitrogen effects on sunflower mean CGR has been described by Nasimet al. (2011) who recorded 16.01 $\mathrm{g} \mathrm{m}^{-2} \mathrm{~d}^{-1}$ mean CGR with application of $180 \mathrm{~kg} \mathrm{~N} \mathrm{ha}^{-1}$. Increase in CGR with nitrogen increment also authenticated the results of Iqbalet al. (2008) who also described positive effects of nitrogen on CGR. The CGR association with total dry matter $\left(\mathrm{R}^{2}=1\right.$ in both years $)$ and achene yield $\left(\mathrm{R}^{2}=0.98\right.$ in 2012 and 0.96 in 2013) was also positive (Fig. 4).

Table 3. Influences of plant population and nitrogen on growth and yield components of sunflower hybrid

\begin{tabular}{|c|c|c|c|c|c|c|c|c|c|c|c|c|}
\hline \multirow{2}{*}{$\begin{array}{l}\text { Treatments } \\
\text { plants ha }^{-1}\end{array}$} & \multicolumn{3}{|c|}{ Crop growth rate (gm-2d-1) } & \multicolumn{3}{|c|}{ Head diameter $(\mathrm{cm})$} & \multicolumn{3}{|c|}{ Number of achenes per head } & \multicolumn{3}{|c|}{ Thousand achene weight } \\
\hline & 2012 & 2013 & Mean & 2012 & 2013 & Mean & 2012 & 2013 & Mean & 2012 & 2013 & Mean \\
\hline 83,333 & $15.11 \mathrm{a}$ & $15.32 \mathrm{a}$ & 15.22 & $15.2 \mathrm{~b}$ & $15.0 \mathrm{~b}$ & 15.1 & $971.0 \mathrm{~b}$ & $942.1 \mathrm{~b}$ & 956.5 & $39.3 \mathrm{~b}$ & $38.3 \mathrm{~b}$ & 38.78 \\
\hline 666,666 & $14.51 \mathrm{a}$ & $14.77 \mathrm{a}$ & 14.64 & $17.4 \mathrm{ab}$ & $17.0 \mathrm{a}$ & 17.16 & $1030 \mathrm{ab}$ & $1009 \mathrm{a}$ & 1020 & $42.6 \mathrm{a}$ & $40.1 \mathrm{ab}$ & 41.32 \\
\hline 55,555 & $13.54 \mathrm{~b}$ & $13.77 \mathrm{~b}$ & 13.66 & $18.8 \mathrm{a}$ & $18.2 \mathrm{a}$ & 18.48 & $1071 \mathrm{a}$ & $1024 \mathrm{a}$ & 1047.9 & $42.7 \mathrm{a}$ & $41.1 \mathrm{a}$ & 41.89 \\
\hline LSD 0.05 & 0.96 & 0.96 & & 2.66 & 1.57 & & 65.71 & 41.26 & & 2.87 & 2.09 & \\
\hline Significance & $*$ & $*$ & & $*$ & $*$ & & $*$ & $*$ & & $*$ & $*$ & \\
\hline \multicolumn{13}{|l|}{$\mathrm{N}$ rates $\mathrm{kg} \mathrm{ha}^{-1}$} \\
\hline 90 & $13.9 \mathrm{~b}$ & $13.4 \mathrm{~b}$ & 13.7 & $15.8 \mathrm{~b}$ & $15.7 \mathrm{~b}$ & 15.7 & $976.4 \mathrm{~b}$ & $946.4 \mathrm{~b}$ & 961.4 & $38.1 \mathrm{~b}$ & $37.9 \mathrm{~b}$ & 38 \\
\hline 120 & $14.4 \mathrm{ab}$ & $14.7 \mathrm{ab}$ & 14.6 & $17.5 \mathrm{a}$ & $16.9 \mathrm{ab}$ & 17.2 & $1034 a b$ & $996 \mathrm{ab}$ & 1015.7 & $42.4 \mathrm{a}$ & $40.3 \mathrm{ab}$ & 41.32 \\
\hline 150 & $14.9 \mathrm{a}$ & $15.2 \mathrm{a}$ & 15.1 & $18.1 \mathrm{a}$ & $17.6 \mathrm{a}$ & 17.8 & $1061.8 \mathrm{a}$ & $1032 \mathrm{a}$ & 1047.3 & $44.1 \mathrm{a}$ & $41.3 \mathrm{a}$ & 42.69 \\
\hline LSD 0.05 & 0.7 & 0.81 & & 1.26 & 1.42 & & 65.74 & 57.17 & & 3.95 & 2.72 & \\
\hline Significance & $*$ & $*$ & & $* *$ & $*$ & & $*$ & $*$ & & $*$ & $*$ & \\
\hline Interaction & NS & NS & & NS & NS & & NS & NS & & NS & NS & \\
\hline Year mean & 14.38 & 14.62 & 14.5 & 17.1 & 16.72 & 16.91 & 1024.4 & 991.9 & 1008.1 & 41.52 & 39.82 & 40.67 \\
\hline
\end{tabular}

Highly significant increase in plant height was recorded with increasing plant population during both study seasons (Table 5). $\mathrm{P}_{1}\left(83,333\right.$ plants $\left.\mathrm{ha}^{-1}\right)$ produced taller plants $(187.3 \mathrm{~cm})$ as compared to $\mathrm{P}_{2}(66,666$ plants $\left.\mathrm{ha}^{-1}\right)$ and $\mathrm{P}_{3}\left(55,555\right.$ plants $\left.\mathrm{ha}^{-1}\right)$ that attained a plant height of 181.2 and $177.0 \mathrm{~cm}$ during season 2012. A similar trend was also seen during 2013. Decreased number of plants per unit area may increase the crop canopy ability to receive the radiation due to more light penetration than denser plants. Increased light intensity disturbs the level of auxin in plants that finally decreased plant height (Allamet al., 2003). Amjadet al. (2011) observed $191 \mathrm{~cm}$ tall plants with a plant population of 83,333 plants $\mathrm{ha}^{-1}$. Positive effects of increasing plant population on plant height were also reported by killi (2004). Our results are not consistent with xiaoet al. (2006) who described a negative effect of increasing plant population on plant height. Plant height highly significantly increased with increasing $\mathrm{N}$ rates (Table 5). Maximum plant height $(191.1 \mathrm{~cm}$ and $186.4 \mathrm{~cm})$ was observed with the $150 \mathrm{~kg} \mathrm{ha}^{-1} \mathrm{~N}$ rate in 2012 and 2013 , respectively. Minimum plant height $(172.5$ and $171.3 \mathrm{~cm}$ in 2012 and 2013, respectively) was obtained with the application of $90 \mathrm{~kg} \mathrm{~N} \mathrm{ha}^{-1}$. While the effect of $\mathrm{N}_{2}(120 \mathrm{~kg}$ $\mathrm{ha}^{-1}$ ) on plant height was statistically at par with $\mathrm{N}_{1}$ and $\mathrm{N}_{3}$. Nitrogen is an important component of nucleic acid, nucleotide and protein that play a vital role in metabolism.
So increase in plant height may be due to the role of $\mathrm{N}$ in enhancing vegetative growth (Al-thabet, 2006). These findings also in concur with Poonia (2000) and Ozer (2004) who reported that nitrogen application increased sunflower plant height.

Head size contributes considerably to achene yield as it affects number of achenes per head. The different plant populations significantly affected the head diameter (Table 3). Maximum head diameter $(18.76,18.19 \mathrm{~cm}$ ) was noted for 55,555 plants ha $^{-1}$ plant population during 2012 and 2013 respectively. More photosynthetic products are available for sunflower head development due to reduced plant height in plots where plant population of 55,555 plants $\mathrm{ha}^{-1}$ was maintained. Head diameter for 66,666 plants $\mathrm{ha}^{-1}$ plant population was statistically similar with the plant population of 55,555 plants $\mathrm{ha}^{-1}$ during both experimentation years. The head diameter was minimum $(15.20 \mathrm{~cm}$ in 2012 and $14.99 \mathrm{~cm}$ in 2013) in plots where 83,333 plants $\mathrm{ha}^{-1}$ plant population was maintained. However, this treatment was at par with $\mathrm{P}_{2}(66,666$ plants $\mathrm{ha}^{-}$) in 2012. Increase in spacing between plants enhanced head diameter (Ali and Osman, 2004). Similar findings were documented by Amjadet al. (2012) who attained $16.43 \mathrm{~cm}$ head size with 83,333 plants $\mathrm{ha}^{-1}$ plant population. Among N rates, plots fertilized with $150 \mathrm{~kg} \mathrm{~N}$ $\mathrm{ha}^{-1}$ produced maximum head diameter $(18.08 \mathrm{~cm})$ in 2012. The situation was similar in 2013 and treatment 150 
$\mathrm{kg} \mathrm{N} \mathrm{ha}{ }^{-1}$ attained a head diameter of $17.55 \mathrm{~cm}$. A regular reduction in head diameter was seen with decreasing $\mathrm{N}$ rates from 150 to $90 \mathrm{~kg} \mathrm{~N} \mathrm{ha}^{-1}$. The treatment $\mathrm{N}_{1}(90 \mathrm{~kg} \mathrm{~N}$ $\mathrm{ha}^{-1}$ ) produced minimum head diameter (15.77 and 15.70 $\mathrm{cm}$ in 2012 and 2013, respectively) and this treatment was statistically at par with $\mathrm{N}_{2}\left(120 \mathrm{~kg} \mathrm{~N} \mathrm{ha}^{-1}\right)$ in 2013. Nitrogen rate of $150 \mathrm{~kg} \mathrm{ha}^{-1}$ produced a head diameter of $20.13 \mathrm{~cm}$ (Amjadet al., 2012).

Number of achenes per head was significantly affected by plant population and $\mathrm{N}$ levels (Table 3). Maximum number of achenes per head was observed from 55,555 plants ha $^{-1}$ plant population (1071.6 and 1024.1) in 2012 and 2013 against minimum attained from 83,333 plants $\mathrm{ha}^{-1}$ plant population (971.0 and 942.1) in 2012 and 2013 respectively. Plant population of 55,555 plants ha $^{-1}$ produced $9.39 \%$ and $8 \%$ more number of achenes per head as compared to 83,333 plants $\mathrm{ha}^{-1}$ plant population during both experimental years. The treatment $\mathrm{P}_{2}(66,666$ plants ha ${ }^{-1}$ ) was statistically at par with $\mathrm{P}_{1}$ and $\mathrm{P}_{3}$ in 2012 . Denser plants compete more with each other for light, water and nutrition (Amjadet al., 2011) that compel sunflower to produce long plants with small achene number (Iqbal and Ashraf, 2006), head diameter (Tenebeet al., 2008) and achene production (Beg et al., 2007). Number of achenes per head was increased regularly with increasing $\mathrm{N}$ rates from 90 to $150 \mathrm{~kg} \mathrm{~N}^{-1}$ (Table 3). Maximum number of achenes per head (1061.8 in 2012 and 1032.8 in 2013) was attained from $\mathrm{N}_{3}(150 \mathrm{~kg}$ $\left.\mathrm{N} \mathrm{ha}^{-1}\right)$ that was statistically at par with $\mathrm{N}_{2}\left(120 \mathrm{~kg} \mathrm{~N} \mathrm{ha}^{-1}\right)$ that produced 1034.9 and 996.50 achenes per head in 2012 and 2013, respectively. The lowest number of achenes per head (976.4 and 946.4) was noted from $\mathrm{N}_{1}\left(90 \mathrm{~kg} \mathrm{~N}^{-1}\right.$ ) and this treatment was also statistically similar to $\mathrm{N}_{2}$ during both study years. Nitrogen contribution towards improvement in source, sink and number of achenes per head was also described by Rondaniniet al. (2006). The biomass production characters like light capture, leaf area and radiation use efficiency was reduced with $\mathrm{N}$ deprivation (Khan etal., 1999) that finally produced less number of achenes per head (Iqbal and Ashraf, 2006). Our results collaborate with findings of Malik et al. (2004); Khaliq and Cheema (2005); Beg et al. (2007) andAmjadet al. (2011).

Different plant populations significantly influenced the 1000 -achene weight in our study (Table 3). Thousand achene weight did not coincide with the achene yield as with increasing plant population thousand achene weight decreased gradually in order of $\mathrm{P}_{3}>\mathrm{P}_{2}>\mathrm{P}_{1}$ treatment. The lowest plant population $\left(55,555\right.$ plants $\left.\mathrm{ha}^{-1}\right)$ produced maximum 1000-achene weight (42.68 and $41.10 \mathrm{~g}$ ) during 2012 and 2013, respectively. While minimum-1000 achene weight (39.27 and 38.29 $\mathrm{g}$ in 2012 and 2013, respectively) was attained from $\mathrm{P}_{1}\left(83,333\right.$ plants ha $\left.{ }^{-1}\right)$. Reduction in 1000-achene weight with increasing plant population was also confirmed from previous studies (ElMohandeset al., 2005; Al-thabet, 2006). Differences in 1000 -achene weight among different $\mathrm{N}$ levels were also significant (Table 3). Thousand achene weight was increased with increasing $\mathrm{N}$ rates and maximum 1000achene weight (44.09 g) was obtained from $150 \mathrm{~kg} \mathrm{~N}^{-1}$ in 2012. The trend was similar in 2013. The minimum 1000-achene weight of 38.07 in 2012 and 37.92 in 2013 was noted from $90 \mathrm{~kg} \mathrm{~N}^{-1}$. The optimum $\mathrm{N}$ supply ensures the improvement in source efficiency and sink capacity. Nasimet al. (2012) recorded a 1000-achene weight of $49 \mathrm{~g}$ with $180 \mathrm{~kg} \mathrm{~N} \mathrm{ha}^{-1}$. Increase in 1000achene weight in response to $\mathrm{N}$ application was also described by Anwar-ul-Haqet al. (2006).

Table 4 illustrated that different plant populations have highly significant effect on achene yield during two years experiment (2012 and 2013). Maximum achene yield (3164.4 kg ha $\mathrm{kg}^{-1}$ in 2012 and $3030.1 \mathrm{~kg} \mathrm{ha}^{-1}$ in 2013) was attained from the plant population of 83,333 plants ha $^{-1}$ and it was followed by the 66,666 plants ha $^{-1}$ plant population that produced achene yield of 2890.3 and $2711.1 \mathrm{~kg} \mathrm{ha}^{-1}$ in 2012 and 2013, respectively. The minimum achene yield (2413.2 and $2289.6 \mathrm{~kg} \mathrm{ha}^{-1}$ ) was produced by 55,555 plants ha $^{-1}$ plant population in 2012 and 2013 respectively. A regular increase in achene yield with increasing plant population $(55,555$ to 83,333 plants $\mathrm{ha}^{-1}$ ) was mainly due to increase in number of plants at harvest as described byAllamet al. (2003). Amjadet al. (2012) attained achene yield of $3662 \mathrm{~kg} \mathrm{ha}^{-1}$ with plant population of 83333 plants ha $^{-1}$.Highly significant and significant enhancement in achene yield was observed with increasing $\mathrm{N}$ rates during 2012 and 2013, respectively (Table 4). Application of $150 \mathrm{~kg} \mathrm{~N} \mathrm{ha}^{-1}$ gave maximum (3066 and $2859.8 \mathrm{~kg} \mathrm{ha}^{-1}$ in 2012 and 2013, respectively) achene yield. Minimum achene yield of $2537.5 \mathrm{~kg} \mathrm{ha}^{-1}$ in 2012 and $2451.6 \mathrm{~kg} \mathrm{ha}^{-1}$ in 2013 was resulted from $90 \mathrm{~kg} \mathrm{~N} \mathrm{ha}^{-1}$. The treatment $\mathrm{N}_{2}$ produced achene yield (2864.4 kg ha ${ }^{-1}$ in 2012 and $2719.4 \mathrm{~kg} \mathrm{ha}^{-1}$ 2013) statistically similar with $\mathrm{N}_{3}$. Significant increase in growth (TDM, CGR) and yield components (head diameter and number of achenes per head) with nitrogen increment ultimately produced significant increase in achene yield (Osman and Awed, 2010). Al-Thabetet al. (2006) and Awaiset al. (2013) recorded a seed yield of $3952 \mathrm{~kg} \mathrm{ha}^{-1}$ and $3196.8 \mathrm{~kg} \mathrm{ha}^{-1}$ from the $150 \mathrm{~kg} \mathrm{~N}^{-1}$ application, respectively. The regression lines drawn revealed a positive association of total dry matter with achene yields (Fig. 3). 
Table 4. Influences of plant population and nitrogen on growth and yield of sunflower hybrid

\begin{tabular}{|c|c|c|c|c|c|c|c|c|c|c|c|c|}
\hline \multirow{2}{*}{$\begin{array}{l}\text { Treatments } \\
\text { Plants ha }^{-1}\end{array}$} & \multicolumn{3}{|c|}{ Achene yield (kg ha $\left.{ }^{-1}\right)$} & \multicolumn{3}{|c|}{ Total dry matter $\left(\mathrm{kg} \mathrm{ha}^{-1}\right)$} & \multicolumn{3}{|c|}{ Harvest index (\%) } & \multicolumn{3}{|c|}{ Oil contents (\%) } \\
\hline & 2012 & 2013 & Mean & 2012 & 2013 & Mean & 2012 & 2013 & Mean & 2012 & 2013 & Mean \\
\hline 83,333 & $3164 \mathrm{a}$ & $3030 \mathrm{a}$ & 3097 & $10197 \mathrm{a}$ & $9930 \mathrm{a}$ & 10064 & $31.2 \mathrm{a}$ & $30.5 \mathrm{a}$ & 30.86 & 40.63 & 39.71 & 40.17 \\
\hline 666,666 & $2890 \mathrm{~b}$ & $2711 \mathrm{~b}$ & 2800 & $9670 \mathrm{a}$ & $9460 \mathrm{a}$ & 9565 & $29.9 \mathrm{a}$ & $28.8 \mathrm{ab}$ & 29.36 & 40.69 & 39.81 & 40.25 \\
\hline 55,555 & $2413 \mathrm{c}$ & $2289 \mathrm{c}$ & 2351 & $8824 b$ & $8636 \mathrm{~b}$ & 8730 & $27.4 \mathrm{~b}$ & $26.6 \mathrm{~b}$ & 26.98 & 40.74 & 40.01 & 40.38 \\
\hline LSD 0.05 & 244.12 & 244.12 & & 832.69 & 798.83 & & 2.23 & 2.37 & & 1.67 & 2.0 & \\
\hline Significance & $* *$ & $* *$ & & $*$ & $*$ & & $*$ & $*$ & & NS & NS & \\
\hline \multicolumn{13}{|c|}{$\mathrm{N}$ rates $\mathrm{kg} \mathrm{ha}^{-1}$} \\
\hline 90 & $2537 \mathrm{~b}$ & $2451 \mathrm{~b}$ & 2494 & $9167 \mathrm{~b}$ & $8760 \mathrm{~b}$ & 8963 & $27.6 \mathrm{~b}$ & 28.0 & 27.8 & $41.8 \mathrm{a}$ & $41.2 \mathrm{a}$ & 41.52 \\
\hline 120 & $2864 \mathrm{a}$ & $2719 \mathrm{a}$ & 2791 & $9552 \mathrm{ab}$ & $9425 \mathrm{a}$ & 9488 & $30.2 \mathrm{a}$ & 28.8 & 29.5 & $41.1 \mathrm{ab}$ & $39.7 \mathrm{ab}$ & 40.39 \\
\hline 150 & $3066 \mathrm{a}$ & $2859 a$ & 2962 & $9971 \mathrm{a}$ & $9842 \mathrm{a}$ & 9907 & $30.7 \mathrm{a}$ & 29.1 & 29.9 & $39.2 \mathrm{~b}$ & $38.6 \mathrm{~b}$ & 38.89 \\
\hline LSD 0.05 & 210.88 & 262.06 & & 612.92 & 664 & & 2.44 & 3.58 & & 2.12 & 2.04 & \\
\hline Significance & $* *$ & $*$ & & $*$ & $*$ & & $*$ & NS & & $*$ & $*$ & \\
\hline \multirow[t]{2}{*}{ Interaction } & NS & NS & & NS & NS & & NS & NS & & NS & NS & \\
\hline & 2822.6 & 2676.9 & 2749.8 & 9564 & 9342.5 & 9453.3 & 29.49 & 28.63 & 29.07 & 40.69 & 39.84 & 40.27 \\
\hline
\end{tabular}

Mean sharing different letters in a column differ significantly at $\mathrm{p} \leq 0.05 * * *=$ significant and highly significant respectively; NS $=$ Non-Significant,

$\mathrm{LSD}=$ least significant difference

TDM accumulation was less upto $2^{\text {nd }}$ harvest $(30$ DAS) then a rapid increase in TDM was observed until physiological maturity (Fig. 2). The total dry matter (TDM) was significant among different plant population and $\mathrm{N}$ rates (Table 4). The data revealed that TDM followed the same pattern for plant population in the whole study. $\mathrm{P}_{1}\left(83,333\right.$ plants $\left.\mathrm{ha}^{-1}\right)$ achieved maximum TDM of $10197.7 \mathrm{~kg} \mathrm{ha}^{-1}$ in 2012 and $9930.6 \mathrm{~kg} \mathrm{ha}^{-1}$ in 2013. However $P_{1}\left(83,333\right.$ plants ha $\left.{ }^{-1}\right)$ was statistically at par with $\mathrm{P}_{2}\left(66,666\right.$ plants $\left.\mathrm{ha}^{-1}\right)$ in producing TDM (9670.4 and $9460.4 \mathrm{~kg} \mathrm{ha}^{-1}$ in 2012 and 2013, respectively). The plant population $\left(83,333\right.$ plants ha $\left.^{-1}\right)$ gained $13.46 \%$ and $13.03 \%$ more TDM over 55,5555 plants $\mathrm{ha}^{-1}$ plant population in 2012 and 2013, respectively. During both experimentation years, $\mathrm{P}_{3}$ $\left(55,5555\right.$ plants $\left.\mathrm{ha}^{-1}\right)$ produced minimum TDM (8824.1 and $\left.8636.5 \mathrm{~kg} \mathrm{ha}^{-1}\right)$. Diepenbrocket al. (2001) attained $9850 \mathrm{~kg} \mathrm{ha}^{-1}$ TDM from 80,000 plants ha ${ }^{-1}$. Similar results were recorded by Nasrollahiet al. (2011).In the year 2012, $\mathrm{N}$ rate of $150 \mathrm{~kg} \mathrm{ha}^{-1}$ produced higher TDM $\left(9971.8 \mathrm{~kg} \mathrm{ha}^{-1}\right)$ which was statistically similar with 120 $\mathrm{kg} \mathrm{N} \mathrm{ha}^{-1}$ with a mean TDM of $9552.8 \mathrm{~kg} \mathrm{ha}^{-1}$ (Table 4). Lowest mean TDM (9167.6 kg ha ${ }^{-1}$ ) was noted in $\mathrm{N}_{1}$ treatment where $\mathrm{N}$ was applied @ $90 \mathrm{~kg} \mathrm{ha}^{-1}$. However $\mathrm{N}_{1}$ and $\mathrm{N}_{2}$ were also at par with each other in producing TDM. Almost similar situation was recorded in 2013 and maximum $\left(9842.6 \mathrm{~kg} \mathrm{ha}^{-1}\right)$ and minimum $\left(8760.0 \mathrm{~kg} \mathrm{ha}^{-1}\right)$ TDM was found in the same treatments as in 2012. However $\mathrm{N}_{1}$ and $\mathrm{N}_{2}$ were statistically different with each other in 2013. Similarly $N_{2}$ and $N_{3}$ were also statistically at par with each other during 2012 and 2013.

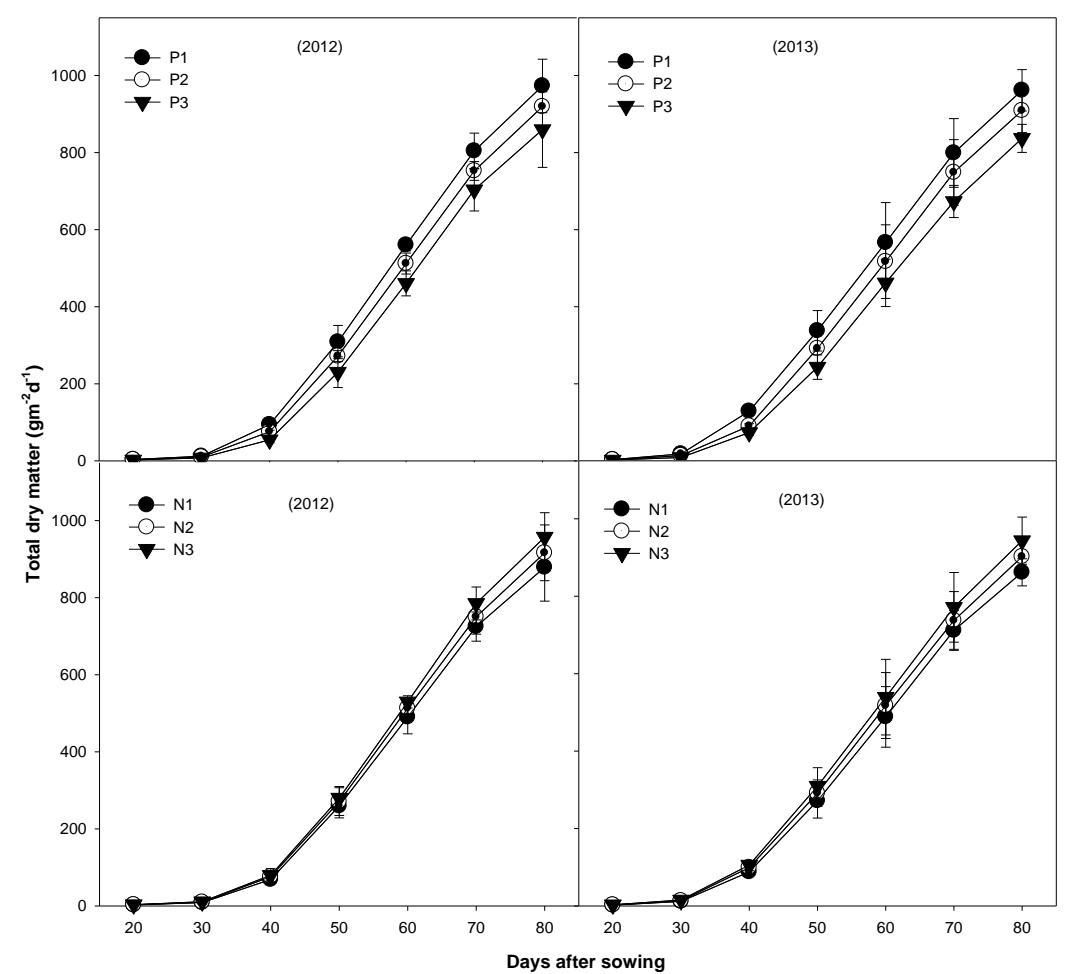

Figure 2. Total dry matter during the crop cycle as affected by various plant populations and $\mathrm{N}$ rates 


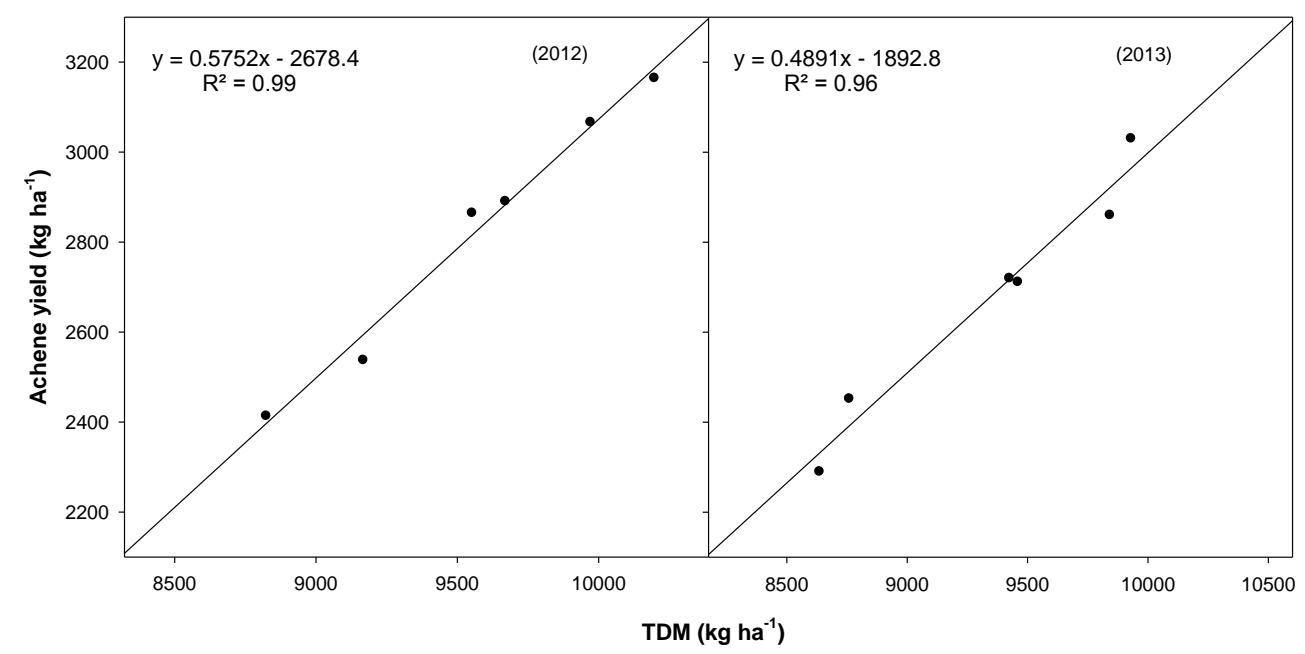

Figure 3.Relationship of sunflower total dry matter with its achene yield
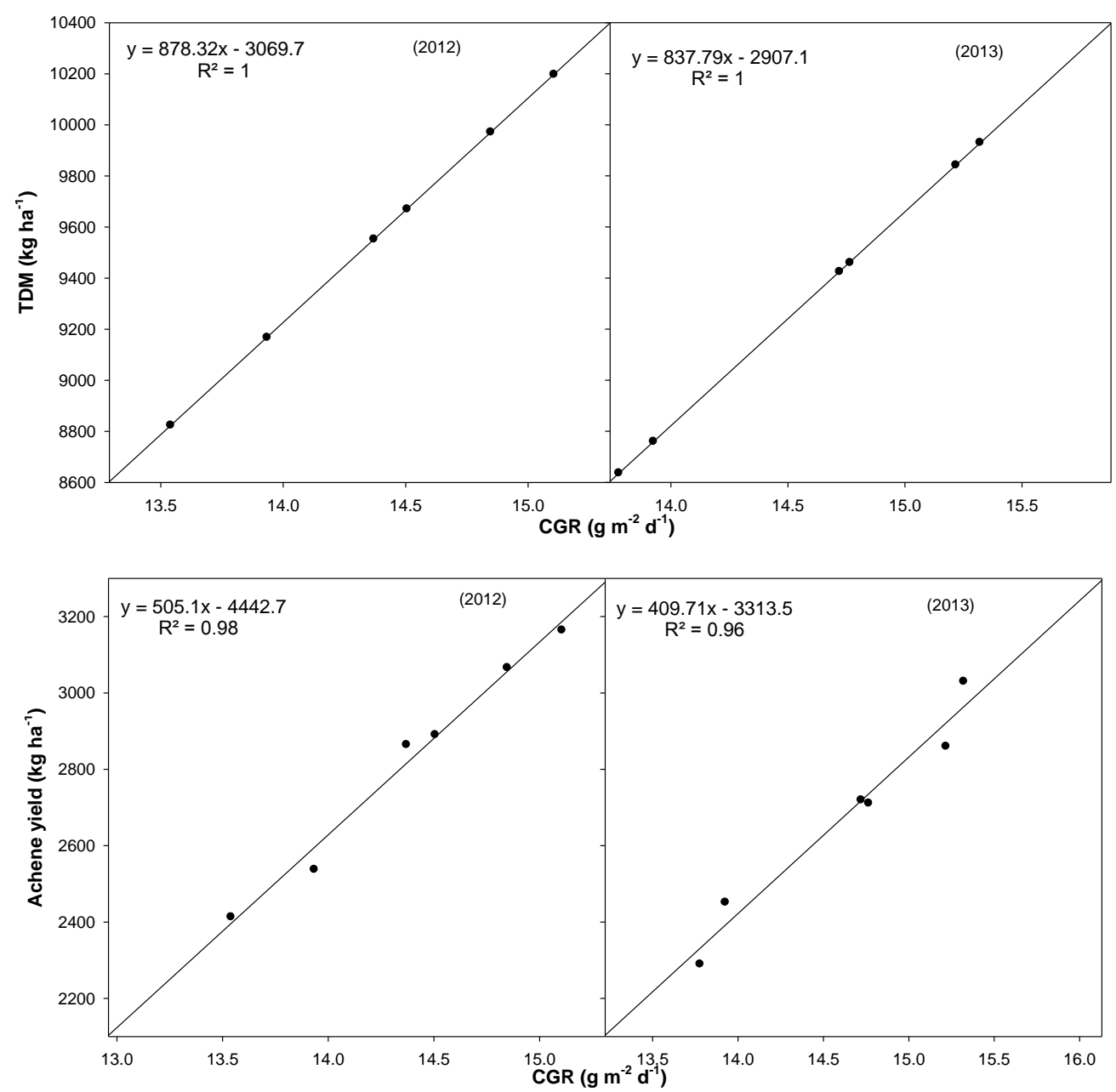

Figure 4.Relationship of sunflower crop growth rate with its total dry matter and achene yield

Harvest index was calculated to estimate efficiency of sunflower to translocate assimilates into economic yield. According to table 4 different plant populations have significant effect on harvest index in both years of study (2012 and 2013). In 2012 highest harvest index (31.21\%) was recorded when 83,333 plants ha $^{-1}$ plant population was maintained but it did not vary significantly with the harvest index gained by the crop having a population of 66,666 plants $\mathrm{ha}^{-1}(29.92 \%)$. The statistically lowest harvest index $(27.36 \%)$ was calculated from 55,555 
plants ha $^{-1}$ plant population. In 2013 maximum (30.51\%) and minimum harvest index $(26.60 \%)$ was calculated with the same plant population as in 2012. However in $2013 \mathrm{P}_{2}\left(66,666\right.$ plants $\left.\mathrm{ha}^{-1}\right)$ achieved a harvest index of $28.79 \%$ which was statistically similar with $\mathrm{P}_{1}$ and $\mathrm{P}_{3}$. Harvest index of $34.68 \%$ was obtained at 10,0000 plants $\mathrm{ha}^{-1}$ plant population (Nasrollahiet al., 2011).Nitrogen effects on harvest index were significant in 2012 but nonsignificant in 2013 (Table 4). During 2012, statistically maximum $(30.66 \%)$ and minimum harvest index $(27.57$ $\%$ ) was attained when sunflower was supplied with 150 and $90 \mathrm{~kg} \mathrm{~N} \mathrm{ha}{ }^{-1}$, respectively. Same treatments gave maximum $(29.12 \%)$ and minimum harvest index (27.97 $\%$ ) in 2013 but these two treatments did not differ significantly. Khaliq and Cheema (2005) calculated harvest index of $33.32 \%$ from $200 \mathrm{~kg} \mathrm{~N} \mathrm{ha}^{-1}$.

A sunflower crop rich in oil contents of excellent quality is the final objective of a farmer. The effect of plant population on oil contents was non-significant during both years of experimentation (Table 4). The sunflower oil contents varied from $39.71 \%$ to $40.74 \%$ among different plant populations. Non-significant differences for oil contents among various plant populations were also stated by Al-Thabet (2006). Our results are not consistent to outcomes of Killi (2004) and Amjadet al., (2012) who informed significant increase in oil concentration and also to Osman and Awed (2010) who described reduction in oil contents with increasing plant population.Negative and significant effects of $\mathrm{N}$ increment on oil contents are present in Table 4. The sunflower oil contents follow the same pattern for different $\mathrm{N}$ rates in both years (2012 and 2013). The oil contents were decreased progressively as $\mathrm{N}$ rates increased from 90 to $150 \mathrm{~kg} \mathrm{ha}^{-1}$. The highest oil contents $(41.84 \%$ and $41.21 \%)$ were observed for $\mathrm{N}_{1}(90 \mathrm{kh} \mathrm{N}$ ha $\left.{ }^{1}\right)$ and lowest $(39.18 \%$ and $38.60 \%)$ for $\mathrm{N}_{3}\left(150 \mathrm{~kg} \mathrm{ha}^{-1}\right)$ during 2012 and 2013 respectively. The treatment $\mathrm{N}_{2}(120$ $\mathrm{kg} \mathrm{ha}{ }^{-1}$ ) was statistically similar with $\mathrm{N}_{1}$ and $\mathrm{N}_{3}$ in providing oil contents $(41.05 \%$ in 2012 and $39.73 \%$ in 2013). As nitrogen is an important constituent of the proteins, so increasing nitrogen rates increased protein synthesis and reduced oil contents (Hussainet al., 2011). Amjadet al. (2012) obtained $38 \%$ oil from sunflower with $150 \mathrm{~kg} \mathrm{~N} \mathrm{ha}{ }^{-1}$. Significant influences of different plant populations and $\mathrm{N}$ rates on oil yield of sunflower were presented in table 5. Maximum oil yield (1285.3 $\mathrm{kg} \mathrm{ha}^{-1}$ in 2012 and $1200.6 \mathrm{~kg} \mathrm{ha}^{-1}$ in 2013) was achieved from the plant population of 83,333 plants $\mathrm{ha}^{-1}$. The minimum oil yield ( 982.2 and $914.7 \mathrm{~kg} \mathrm{ha}^{-1}$ ) was produced by 55,555 plants $\mathrm{ha}^{-1}$ plant population in 2012 and 2013 respectively.The maximum oil yield (1204.6 and 1102.7 $\mathrm{kg} \mathrm{ha}^{-1}$ in 2012 and 2013, respectively) was obtained with the application of $150 \mathrm{~kg} \mathrm{~N} \mathrm{ha}^{-1}$. Minimum oil yield of $1060.8 \mathrm{~kg} \mathrm{ha}^{-1}$ in 2012 and $1009.7 \mathrm{~kg} \mathrm{ha}^{-1}$ in 2013 was recorded with $90 \mathrm{~kg} \mathrm{~N} \mathrm{ha}^{-1}$.

Table 5.Influences of Plant population and nitrogen on plant height and oil yield of sunflower

\begin{tabular}{|c|c|c|c|c|c|c|}
\hline \multirow{2}{*}{$\begin{array}{l}\text { Treatments } \\
\text { plants ha }^{-1}\end{array}$} & \multicolumn{3}{|c|}{ Plant height $(\mathrm{cm})$} & \multicolumn{3}{|c|}{ Oil yield $\left(\mathrm{kg} \mathrm{ha}^{-1}\right)$} \\
\hline & 2012 & 2013 & Mean & 2012 & 2013 & Mean \\
\hline 83,333 & $187.3 \mathrm{a}$ & $186.3 \mathrm{a}$ & 186.8 & $1285.3 \mathrm{a}$ & $1200.6 \mathrm{a}$ & 1242.95 \\
\hline 666,666 & $181.2 \mathrm{~b}$ & $179.6 \mathrm{ab}$ & 180.4 & $1178.3 \mathrm{~b}$ & $1077.0 \mathrm{~b}$ & 1127.65 \\
\hline 55,555 & $177.0 \mathrm{c}$ & $173.0 \mathrm{~b}$ & 175.0 & $981.2 \mathrm{c}$ & $914.7 \mathrm{c}$ & 947.95 \\
\hline LSD 0.05 & 3.97 & 8.35 & & 90.78 & 82.63 & \\
\hline Significance & $*$ & $*$ & & $*$ & $*$ & \\
\hline \multicolumn{7}{|l|}{$\mathrm{N}$ rates $\mathrm{kg} \mathrm{ha}^{-1}$} \\
\hline 90 & $172.5 \mathrm{~b}$ & $171.3 \mathrm{~b}$ & 171.9 & $1204.6 \mathrm{a}$ & $1102.7 \mathrm{a}$ & 1153.65 \\
\hline 120 & $182.0 \mathrm{ab}$ & $181.2 \mathrm{ab}$ & 181.6 & $1180.3 \mathrm{a}$ & $1079.9 \mathrm{a}$ & 1130.1 \\
\hline 150 & $191.1 \mathrm{a}$ & $186.4 \mathrm{a}$ & 188.8 & $1060.8 \mathrm{~b}$ & $1009.7 \mathrm{~b}$ & 1035.25 \\
\hline LSD 0.05 & 12.21 & 10.06 & & 108.83 & 63.02 & \\
\hline Significance & $* *$ & $* *$ & & $*$ & $*$ & \\
\hline Interaction & NS & NS & & NS & NS & \\
\hline Year mean & 181.9 & 179.6 & 180.75 & 1148.6 & 1064.1 & 1106.3 \\
\hline
\end{tabular}

Mean sharing different letters in a column differ significantly at $\mathrm{p} \leq 0.05$

$*, * *=$ significant and highly significant respectively; NS = Non-Significant, , LSD = least significant difference

\section{Correlation between achene yield and components of yield}

Table 6 reveals correlation co-efficients of achene yield with growth and components of achene yield. Achene yield was correlated positively and highly significantly with crop growth rate, harvest index and total dry matter and during both years (2012 and 2013). Pooled data also showed similar results. However correlation of achene yield with head diameter and number of achenes per head was negative and non-significant. Similarly correlation of 1000 -achene weight with achene yield was positive and non-significant in 2012 but negative and nonsignificant in 2013. Pooled data also indicates a nonsignificant association of 1000-achene weight with achene yield. 
Table 6. Correlation of sunflower achene yield with some studied parameters

\begin{tabular}{llcc}
\hline \multirow{2}{*}{ Parameters } & \multicolumn{3}{c}{ Correlation co-efficient (r) } \\
\cline { 2 - 4 } & $\mathbf{2 0 1 2}$ & $\mathbf{2 0 1 3}$ & Pooled \\
\hline Crop growth rate & $0.99^{* *}$ & $0.98^{* *}$ & $1.00^{* *}$ \\
Head diameter & $-0.34^{\mathrm{ns}}$ & $-0.49^{\mathrm{ns}}$ & $-0.41^{\mathrm{ns}}$ \\
Number of achenes per head & $-0.22^{\mathrm{ns}}$ & $-0.22^{\mathrm{ns}}$ & $-0.22^{\mathrm{ns}}$ \\
1000-achene weight & $0.14^{\mathrm{ns}}$ & $-0.16^{\mathrm{ns}}$ & $0.01^{\mathrm{ns}}$ \\
Total dry matter & $0.99^{* *}$ & $0.98^{* *}$ & $1.00^{* *}$ \\
Harvest index & $0.98^{* *}$ & $0.98^{* *}$ & $0.99^{* *}$ \\
\hline
\end{tabular}

$\mathrm{ns}=$ Non-significant, ${ }^{*}, *$ significant at $1 \%$ and $5 \%$ probablity

\section{CONCLUSIONS}

Results in table 3,4 \& 5 and figure 2,3 \& 4 reveals that sunflower (Hysun-33) should be planted in highpopulationof 83,333 plants $\mathrm{ha}^{-1}$ (keeping row to row and plant to plant distance of 60 and $20 \mathrm{~cm}$, respectively) with nitrogen level of $150 \mathrm{~kg} \mathrm{ha}{ }^{-1}$ to attain maximum achene yield. Increased plant populations $(66,666$ and 83,333 plants $\mathrm{ha}^{-1}$ ) have a decreasing effect onyield components (head diameter, thousand achene weights and number of achene per head and) however this effect was over-compensated by more number of plants per meter square.

\section{LITERATURE CITED}

Abdel-Motagally, F.M.F. and E.A. Osman. 2010. Effect of nitrogen and potassium fertilization on productivity of two sunflower cultivars under east of EI-ewinate conditions. American-Eurasian J. Agric. Environ. Sci. 8: 397-401.

Adediran, J.A., L.B. Taiwo, M.O. Akande, O.J. Idowu, R.A. Sobulo and J.A. Adediran. 2004. Application of organic and inorganic fertilizer for sustainable maize and cowpea yields in Nigeria. J. Plant. Nut. 27(7): 1163-1181.

Ahmad, S., R. Ahmad, M.Y. Ashraf, M. Ashraf and E.A. Waraich. 2009. Sunflower (Helianthus annuusL.) response to drought stress at germination and seedling growth stages. Pak. J. Bot.41(2): 647-654.

Ali, E.A. and E.B.A. Osman. 2004. Effect of hill spacing fertigation using drip irrigation system in sandy calcareous soil on the productivity of some safflower genotypes. The 2nd Syrian-Egyptian Conf., El-Baath Univ., Syria.

Ali, H., M. Riaz, A. Zahoor and S. Ahmad. 2011. Response of sunflower hybrids to management practices under irrigated arid-environment. African J. Biotech. 10(14): 2666-2675.

Ali, H., S.A. Randhawa and M. Yousaf. 2004. Quantitative and qualitative traits of sunflower (Helianthus annusL.) as influenced by planting dates and nitrogen application. Int. J. Agri. Bio. 6: 410-412.

Allam, A.Y., G.R. El-Nagar and A.H. Galal. 2003. Response of two sunflower hybrids to planting dates and densities. ActaAgronomicaHungarica, 51: 25-35.

Al-Thabet, S.S. 2006.Effect of plant spacing and nitrogen levels on growth and yield of sunflower (Helianthus Annus L.). J. King Saud Univ. Agric. Sci. 19: 1-11.

Amjad, A., M. Afzal, I. Rasool, S. Hussain and M. Ahmad. 2011. Sunflower (Helianthus annuus L.) hybrids performance at different plant spacing under agro-ecological conditions of Sargodha, Pakistan. International conference on food engineering and biotechnology.IPCBEE vol. 9, IACSIT Press, Singapoore.

Amjed, A., A. Ahmad, T. Khaliq, M. Afzal and Z. Iqba. 2012. Achene yield and quality response of sunflower hybrids to nitrogen at varying planting densities. International
Conference on Agriculture, Chemical and Environmental Sciences (ICACES') Oct. 6-7, Dubai (UAE).

Anwar-ul-Haq, A., M.A. Rashid, M.A. Butt, M. Akhter, Aslam and A. Saeed. 2006. Evaluation of sunflower (Helianthus annuusL.) hybrids for yield and yield components in central Punjab. J. Agric. Res.44: 277-285.

Awais, M., A.Wajid, A. Ahmad and A. Bakhsh.2013. Narrow plant spacing and nitrogen application enhances sunflower (Helianthus annuusL.) productivity. Pak. J. Agri. Sci. 50(4): 689-697.

Badar, H., M.S. Javed, A. Ali and Z. Batool. 2002. Production and marketing constraintslimiting sunflower production in Punjab (Pakistan). Int. J. Agric. Bio. 4: 267-271.

Bakht, J., M. Shafi, M. Yousaf and Hamid Ullah Shah.2010a. Physiology, phenology and yield of sunflower (autumn) as affected by NPK fertilizer and hybrids. Pak. J. Bot. 42: 19091922.

Beg. A., S.S. Pourdad and S. Alipour. 2007. Row and plant spacing effects on agronomic performance of sunflower in warm and semi-cold areas of Iran. Helia, 30: 99-104.

Diepenbrock, W., M. Lang and B. Feil. 2001. Yield and quality of sunflower as affected by row orientation, row spacing and plant density. Die Bodenkultur, 52: 29-36.

El-Mohandes, S., E.A. Ali and E.B.A. Osman. 2005. Response of two sunflower hybrids to the number of NPK fertilizers splittings and plant densities in newly reclaimed soil. Assiut J. Agric. Sci. 36(5): 27-38.

Fayyaz-ul-Hassan, G. Qadir and M.A. Cheema. 2005. Growth and development of sunflower in response to seasonal variations. Pak. J. Bot.37: 859-864.

Govt. of Pakistan.2009b. Economic Survey of Pakistan. Ministry of Food, Agriculture and Livestock, Finance Division, Economic Advisor Wing, Islamabad, Pakistan, PP: 23.

Govt. of Pakistan. 2013. Economic Survey of Pakistan, 20122013. Finance Division, Economic Advisory Wing, Islamabad, Pakistan, PP: 23.

Habib, H., S.S. Mehdi, A. Rashid and M. A. Anjum. 2006. Genetic association and path analysis for seed yield in sunflower. Pak. J. Agric. Sci. 43: 136-139.

$\mathrm{Hu}$, J., B. Yue, W. Yuan and B.A. Vick. 2008. Growing sunflower plants from seed to seed in small plots in green house. Helia, 48: 119-126.

Hunt, R. 1978. Plant growth analysis. Edward Arnold, U.K.: 2638 .

Hussain, S.S., F.A. Misger, A. Kumar and M.H. Baba. 2011. Response of nitrogen and sulphur on biological and economic yield of sunflower (Helianthus annuusL.). Res. J. Agri. Sci. 2: 308-310.

Iqbal, J., B. Hussain, M.F. Saleem, M.A. Munir and M. Aslam. 2008. Bioeconomics of autumn planted sunflower (Helianthus annuusL.) hybrids under different NPK application. Pak. J. Agri. Sci. 45: 19-24. 
Iqbal, J., M.A. Malik, B. Hussain and M.A. Munir. 2007. Performance of autumn plantedsunflower hybrids under different planting patterns. Pak. J. Agric. Sci. 4: 587-591.

Iqbal, N. and M.Y. Ashraf. 2006. Does seed treatment with glycinebetaine improve germination rate and seedling growth of sunflower (Helianthus annuusL.) under osmotic stress?.Pak. J. Bot.38: 1641-1648.

Khaliq, A. and Z.A. Cheema. 2005. Influence of irrigation and nitrogen management on some agronomic traits and yield of hybrid Sunflower (Helianthus annuus L.). Int. J. Agri. Biol. 7: 915-919.

Khan, M. A., K. Ahmad and J. Ahmad. 1999. Effect of Potassium Levels on the Yield of Sunflower. Pakistan J. Biol. Sci. 2(2): 402-403.

Khan, M.S., M.S. Swati, I.H. Khalil and A. Iqbal. 2003. Heterotic studies for various characters in sunflower (Helianthus annuus L.). Asian J. of Plant Sci. 2: 1010-1014.

Killi, F. 2004. Influence of different nitrogen levels on productivity of oil seed and confection sunflower (Helianthus annuusL.) under varying plant populations. Int J. Agri. Bio. 6: 594-598.

Malik, M.A., M.F. saleem. M. Sana and A. Rehman. 2004. Suitable level of $\mathrm{N}, \mathrm{P}$ and $\mathrm{K}$ for harvesting the maximum economic return of sunflower. Int. J. Agri. Bio. 6: 240-242.

Munir, M.A., M.A. Malik and M.F. Saleem. 2007. Impact of integration of crop manuring and nitrogen application on growth, yield and quality of spring planted sunflower (Helianthus annuusL.). Pak. J. Bot. 39: 441-449.

Nasim, W., A. Ahmad, A. Wajid, J. Akhtar and D. Muhammad. 2011. Nitrogen effects on growth and development of sunflower hybrids under agro-climatic conditions of Multan Pak. J. Bot. 43: 2083-2092.

Nasim, W., A. Ahmad, H.M. Hammad, H.J. Chaudhary and M.F.H. Munis. 2012. Effect of nitrogen on growth and yield of sunflower under semi-arid conditions of Pakistan. Pak. J. Bot. 44(2): 639-648.
Nasrollahi, H., A.H. Shirani-Rad, A. Khourgami and K. Haghiabi. 2011. Effect of plant density on yield and oil percent of sunflower early cultivars in second culture. Int. J. Sci. Advanced Tech. 1(10): 71-77.

Osman, E.B.O., M.M.M. Awed. 2010. Response of sunflower (Helianthus annuusL.) to phosphorus and nitrogen fertilization under different plant spacing at New Valley.Ass. Univ. Bull. Environ. Res. 13(1): 11-19.

P. O. D. B. 2006. Oilseed development strategy.Pakistan oilseed development board.Ministry of food, agriculture and livestock, Islamabad-Pakistan.

Rondanini, D.P., R. Savin, A.J. Hall. 2006. Estimation of physiological maturity in sunflower as a function of fruit water concentration. Europ. J. Agron. 30: 1-15.

Saleem, M.F., B.L. Ma, M.A. Malik, M.A. Cheema and M.A. Wahid. 2008. Yield and quality response of autumn-planted sunflower (Helianthus annuusL.) to sowing dates and planting patterns. Can. J. Plant Sci. 88: 101-109.

Scheiner, D.J., F.H. Gutierrez-Boem and R. Lavado. 2002. Sunflower nitrogen requirement and $15 \mathrm{~N}$ fertilizer recovery in Western Pampas, Argentina. Eu. J. Agron. 17: 73-79.

Steel, R.G.D., J.H. Torrie and D.A. Dickey. 1997. Principles and Procedures of Statistics. A Biometrical Approach.3rd ED. McGraw Hill Book. Int. Co. New York: PP: 400-428.

Tenebe, V.A., U.R. Pal, C.A.C. Okonkwo and B.M. Auwalu. 2008. Response of rainfed sunflower (Helianthus annuusL.) to nitrogen rates and plant population in the semi-arid savanna region of Nigeria. J. Agron. and Crop Sci. 177: 2072015.

Tóth, V.R., I. Mészáros, S.J. Palmer, S. Veres and I. Précsényi. 2002. Nitrogen deprivation induces changes in the leaf elongation zone of maize seedlings. BiologiaPlantarum, 45: 241-247.

Yasin, M., A. Mahmood and Z. Iqbal. 2011. Growth and yield response of autumn sunflower (Helianthus annuusL.) to varying planting densities under subtropical conditions. Int. J. Agric. Appl. Sci. 3(2): 86-88. 